\title{
Practice-Based Research in Digital Arts: A Case Study of Wat Phumin, Nan Province, Thailand
}

\section{Tawipas Pichaichanarong}

Suan Sunandha International School of Arts, Suan Sunandha Rajabhat University, Nakhon Pathom Campus, Thailand

E-mail: tawipas.pi@ssru.ac.th

\begin{abstract}
Thai mural paintings have played a significant role in Thai society since The Sukhothai Kingdom period (1238-1438 AD) until the present. Wattana Boonjub (2009) points out that Mural painting was used for teaching the Thai people in the past. Throughout history, temples have become a crucial part of Thai' lives; for example, Wat Phumin in Nan Province. Wat Phumin has exceptional architecture, beautiful visual presentations of Buddhist storytelling on the walls which depict scenes from the Buddhist Jataka tales, and scenes of everyday life in Nan. These unique characteristics have attracted many visitors to this temple over the years. Also, when those interested visit Wat Phumin, they experience this temple as a Museum. Loïc Tallon et al. (2008) suggests that the museum experience provides an appropriate situation for learning history in an unconventional setting. As a result, previous research titled "Visual Research Practices on Thai Lanna Mural Painting: A Case Study of Wat Phumin, Nan Province" was presented at The 4th International Conference for Asia Pacific Arts Studies (ICAPAS 2016). The results indicated that the information concerning the Lanna mural paintings inside the temples was overwhelming. However, no directions are facilitating Thai and foreign visitors in viewing and understanding at the first episode of storytelling on Lanna mural paintings inside Wat Phumin. Therefore, this research is the result of finding a solution to facilitating visitors in viewing Buddhist Jataka tales through digital arts and digital technology (such as responsive web design, QR codes, etc.) with practice-based design research.
\end{abstract}

Keywords: responsive web design, QR codes, wat phumin, practice-based design research

\begin{abstract}
ABSTRAK
Lukisan mural Thailand telah memainkan peran penting dalam masyarakat Thailand sejak periode Kerajaan Sukhothai (1238-1438 M) hingga saat ini. Wattana Boonjub (2009) menunjukkan bahwa lukisan Mural digunakan untuk mengajar orang-orang Thailand di masa lalu. Sepanjang sejarah, kuil telah menjadi bagian penting dari kehidupan Thailand; misalnya, Wat Phumin di Provinsi Nan. Wat Phumin memiliki arsitektur yang luar biasa, presentasi visual yang indah dari cerita Buddha di dinding yang menggambarkan adegan dari kisah Buddha Jataka, dan adegan kehidupan sehari-hari di Nan. Karakteristik unik ini telah menarik banyak pengunjung ke kuil ini selama bertahun-tahun. Juga, ketika mereka yang tertarik mengunjungi Wat Phumin, mereka merasakan candi ini sebagai Museum. Loïc Tallon et al. (2008) menunjukkan bahwa pengalaman museum memberikan situasi yang tepat untuk belajar sejarah dalam lingkungan yang tidak konvensional. Sebagai hasilnya, penelitian sebelumnya yang berjudul
\end{abstract}


Tawipas Pichaichanarong, Practice-Based Research in Digital Arts: ...

"Praktik Penelitian Visual pada Lukisan Mural Lanna Thailand: Studi Kasus Wat Phumin, Provinsi Nan" dipresentasikan pada Konferensi Internasional ke-4 untuk Studi Seni Asia Pasifik (ICAPAS 2016). Hasilnya menunjukkan bahwa informasi mengenai lukisan mural Lanna di dalam kuil sangat banyak. Namun, tidak ada arahan yang memfasilitasi pengunjung Thailand dan wisatawan asing dalam melihat dan memahami episode pertama pada cerita tentang lukisan mural Lanna di dalam Wat Phumin. Oleh karena itu, penelitian ini adalah hasil dari menemukan solusi untuk memfasilitasi pengunjung dalam melihat cerita Buddha Jataka melalui seni digital dan teknologi digital (seperti desain web responsif, kode $Q R$, dll.) dengan penelitian desain berbasis praktik.

Kata Kunci: desain web responsif, kode $Q R$, wat phumin, riset desain berbasis praktik

\section{INTRODUCTION}

The results from the author's previous research titled "Visual Methods in Social Research on Lanna Mural Painting: A Case Study of Wat Phumin, Nan Province" presented at The 4th International Conference for Asia Pacific Arts Studies (ICAPAS 2016) indicated that information regarding the Lanna mural painting inside the temple is overwhelming. This is because there are no directions facilitating Thai and foreign visitors in where to first begin in terms of the episodes of the storytelling inside the targeted site. Therefore, this paper results from attempts to find an apt solutions through practice-based research methodology.

\section{Literature Review}

Identifying a solution to facilitate the comprehension Thai and foreign visitors of Thai Lanna mural paintings is not an easy task. This research has adopted practice-based research methodology through practice in its attempt to do so.

\section{Practice-Based Research}

Practice-based research is an authentic investigation to garner new insights from a variety of practices and the outcomes of those practices. According to Laurene Vaughan (2017), the author describes practice-based research as the collection of knowledge through creativity resultings in the scheme of designs, music, digital media, performances and exhibitions (p.56). This research was designed to explore an example solution to facilitate the visitors' viewing experience of Lanna mural paintings at Wat Phumin, Nan province using different approaches. 


\section{Wat Phumin as A Museum}

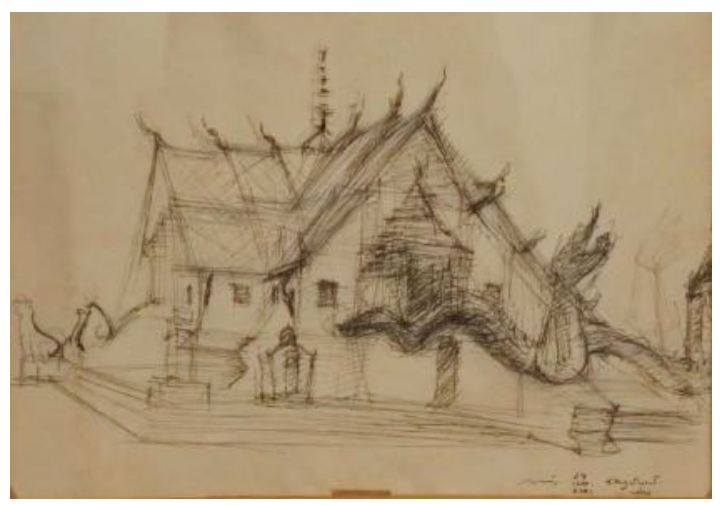

Figure 1. Drawing of Wat Phumin, Nan province by Assist. Prof. Fua Haripitak (Image accessed 27 May 2020 from https://www.silpa-mag.com/news/article_8542)

Wat Phumin in Nan province as figure 1, presents a dazzling visual presentation of Buddhist storytelling on the walls (T. Pichaichanarong, 2016). In this research, the setting at Wat Phumin has been treated as a museum. Ana Maria Theresa Labradorpp (2018) points out that museums can be sites for investigation (p.78). Therefore, treating Lanna mural paintings as museums would suffice as mentioned.

\section{Objectives}

1. Analyzing difference approaches to develop a solution through practice-based research.

2. Develop tools to facilitate Thai and foreign visitors who attend Wat Phumin in Nan province.

3. Use digital technology, such as responsive web design, QR codes to be examples for solutions in this research.

\section{Definition of Terms}

\section{Responsive Web Design}

This research chose a website to act as the channel to facilitate Thai and foreign visitors' experience of Thai Lanna mural paintings at Wat Phumin, Nan province because since the invention of the internet by Tim Berners-Lee 1989, it has become a widely used means of communication. According to Jason A. Clarke, (2015) there was a change in web development from 2010 to present. Web development has expanded to mobile platforms with mobile computing which includes browsing the web, watching movies, typing on word processors, etc. Responsive web design is a set of know-how tools for creating web sites that work on various devices and screens (p.2). 
Tawipas Pichaichanarong, Practice-Based Research in Digital Arts: ...

\section{QR Code}

QR code is a readable code comprising a batch of black and white strips, used for linking URLS reading by a camera on a smartphone, as derived from the Japanese industry in 1994 (Retrieved from the internet on February $27^{\text {th }}, 2016$ ). The QR code was introduced to this research with responsive web design for connecting to videos on the YouTube channel. Indeed, video is itself another means of facilitating visitors.

\section{METHODOLOGY}

\section{Practice-Based Research Design}

The first step in practice-based practice in this research starts with the inspiration from Assistant Professor Fua Haripitak (1910-1993) who studied in India during 1940-1946, at Visva Bharati University, Santiniketan, India. He saw how the Indian government has copied drawing samples of mural paintings from various ancient sites in order to preserve India's heritage. After Assistant Professor Fua Haripitak returned to Thailand, he decided to copy drawing samples from various Thai temples in Thailand.

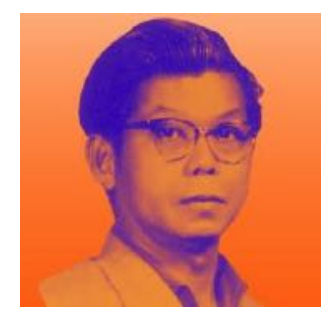

Figure 2. Assist. Prof. Fua Haripitak, Thai National Artist (Image accessed 27 May 2020 from https://www.the101.world/fua-haripitak/)

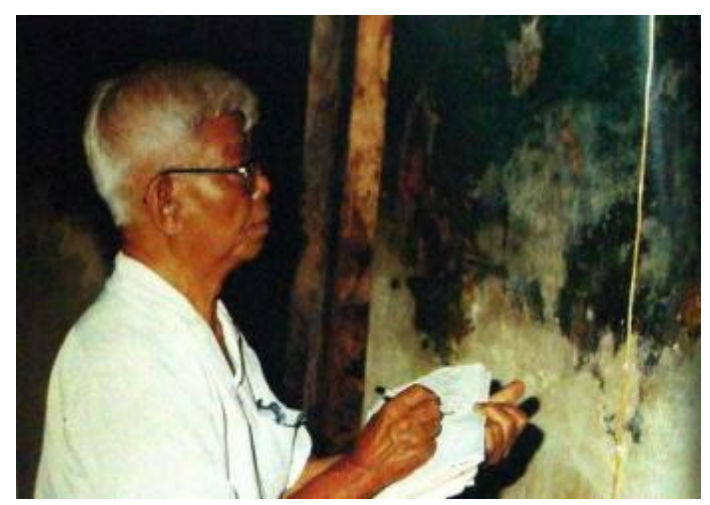

Figure 3. Assist. Prof. Fua Haripitak studied mural paintings before he copied the samples (Image accessed 27 May 2020 from https://www.greatstarsartshow.com/art/1268) 


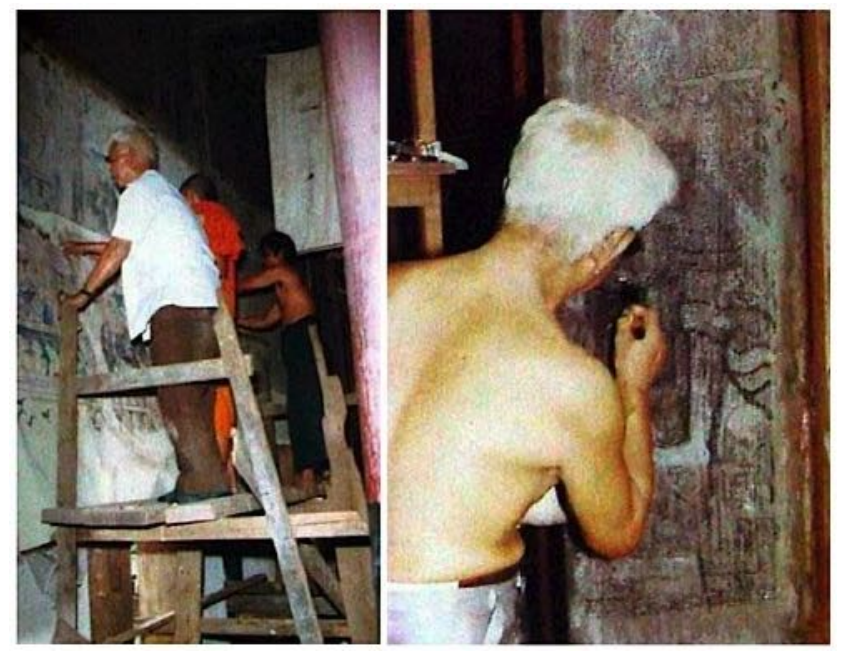

Figure 4. Assist. Prof. Fua Haripitak copied drawing samples from mural painting in order to preserve Thailand's national heritage (Image accessed 27 May 2020 from https://www.bloggang.com/viewdiary.php?id=haiku\&group=2\&month=05-2010\&date=11)

As a result, this research adopted the copy drawing sample technique for the Thai Lanna mural paintings at Wat Phumin, Nan province. In order to copy the entire drawing sample technique, this project required the entire photograph of Thai Lanna mural painting at the temple. Also, those photographs are in digital files, and they can refer as "digital arts" in this research.

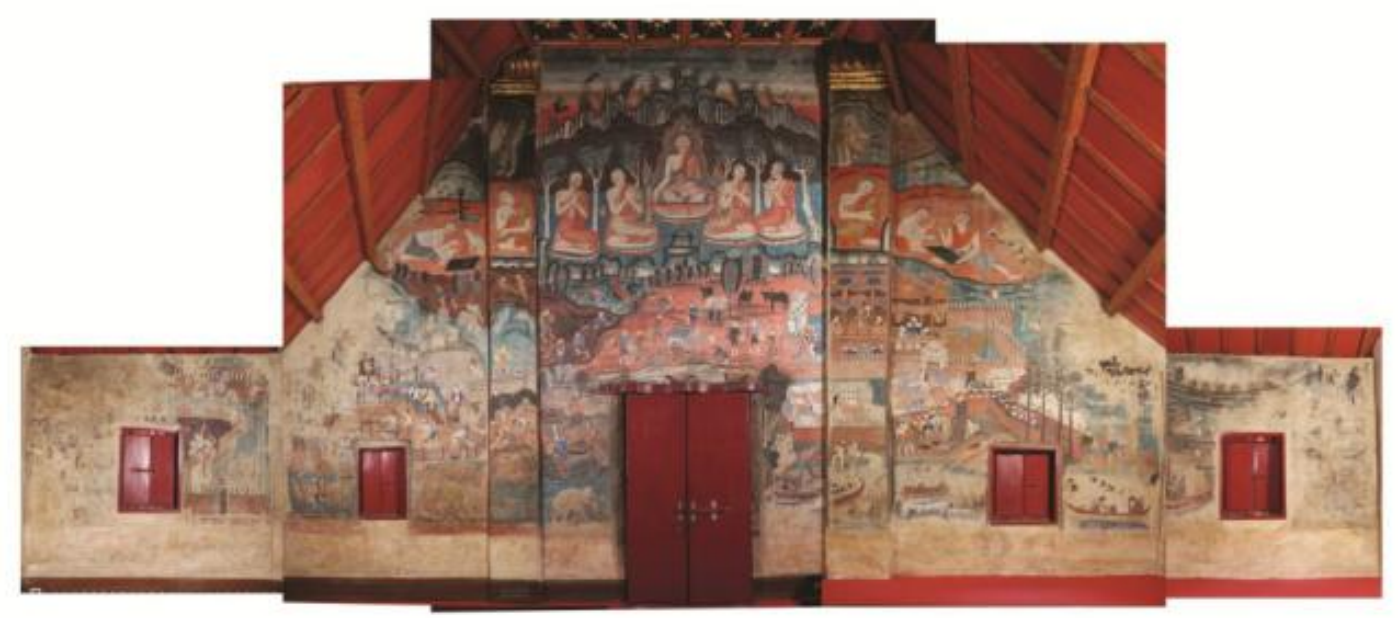

Figure 5. Thai Lanna mural painting at Wat Phumin, Nan province (North) 


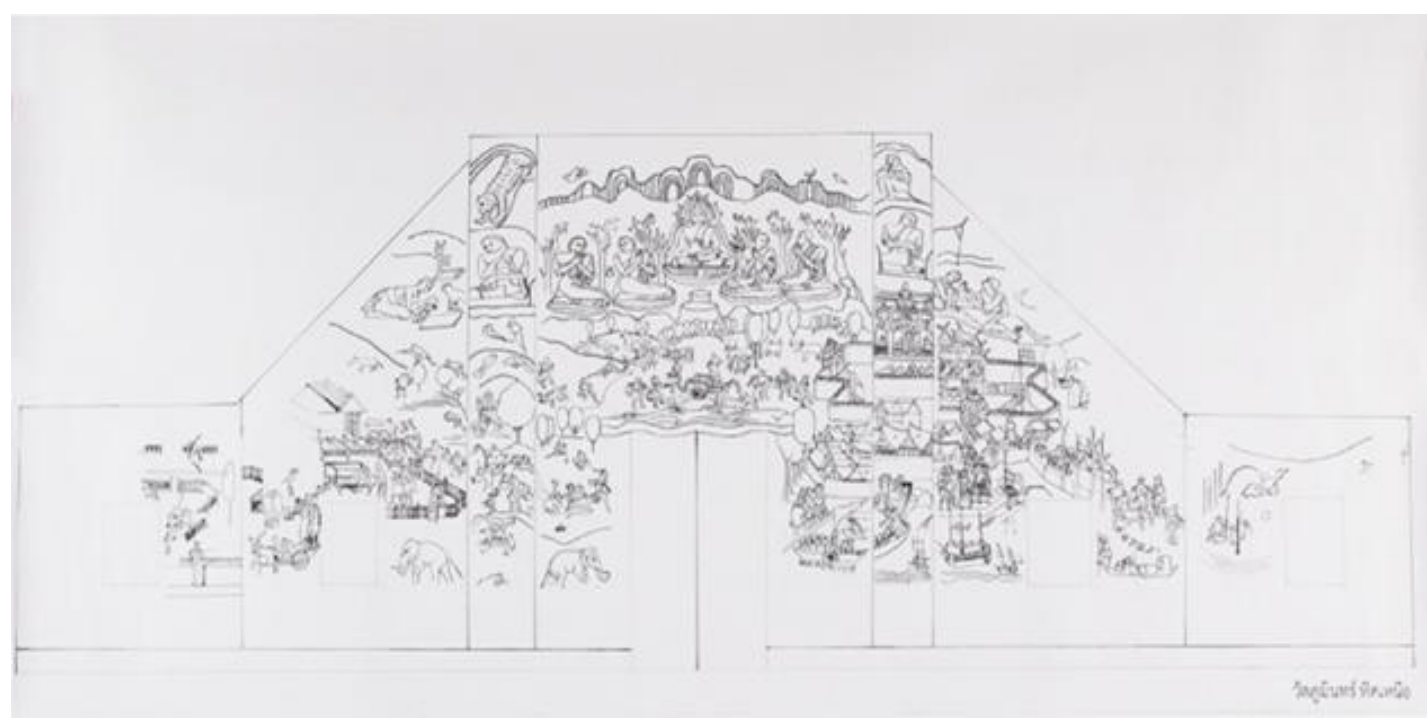

Figure 6. Copy drawing of Thai Lanna mural painting at Wat Phumin, Nan province (North)

The author's previous research (2016) identified three major categories for storytelling on Lanna mural paintings at Wat Phumin as follows: (i) 'The Story of the Buddha'; Second, (ii) 'The Previous Life Stories of the Buddha', and Third 'Ordinary Life of the Local People. This research selected 'Previous Life Stories of the Buddha' as the focus of practice-based research. To understand the storytelling in 'Previous Life Stories of the Buddha', the researcher studied the relevant books and interviewed those with the knowledge and expertise. First, to understand Thai mural paintings in general, it is tradition when people visit the Thai temple, they first come from the direction of the north of the temple, then follow clockwise to the east, south, and west as shown below (figure7). 
IJCAS Vol. 6 No. 2, December 2019 | p-ISSN 2339-191X | e-ISSN 2406-9760

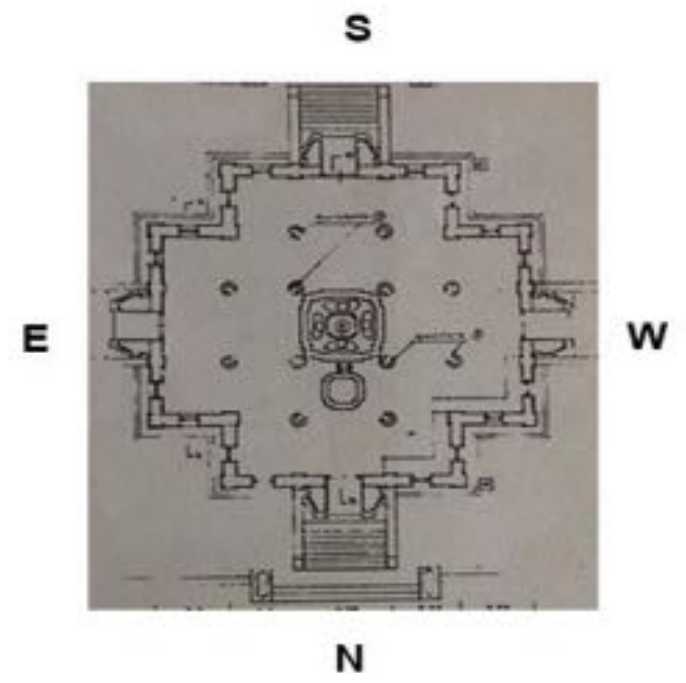

Figure 7. Direction of Wat Phumin, Nan province (Image from: The 7th Reginonal Office of Fine Arts, Nan province)

The second step of the practice-based practice research adopted the Archaeological Mapping and Universal Transverse Mercator (UTM) coordinate for the Thai Lanna mural paintings at Wat Phumin. as shown below (figure 8 and figure 9).

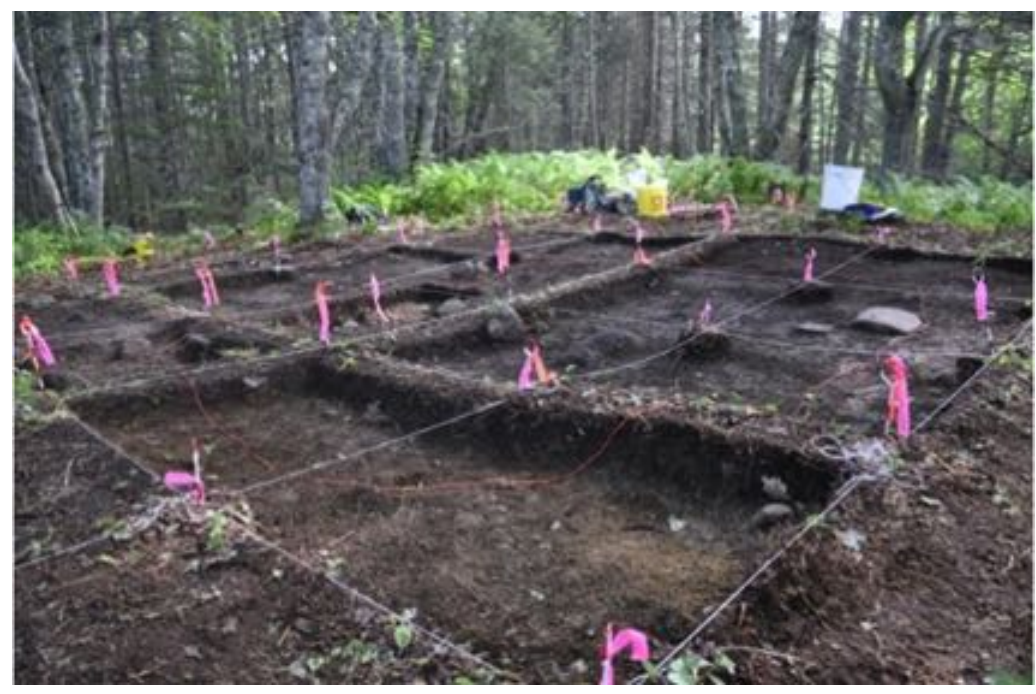

Figure 8. Archaeological Mapping (Image accessed 27 May 2020 from https://coastalarchaeology.wordpress.com/2012/07/19/archaeological-mapping-with-idraw/) 
Tawipas Pichaichanarong, Practice-Based Research in Digital Arts: ...

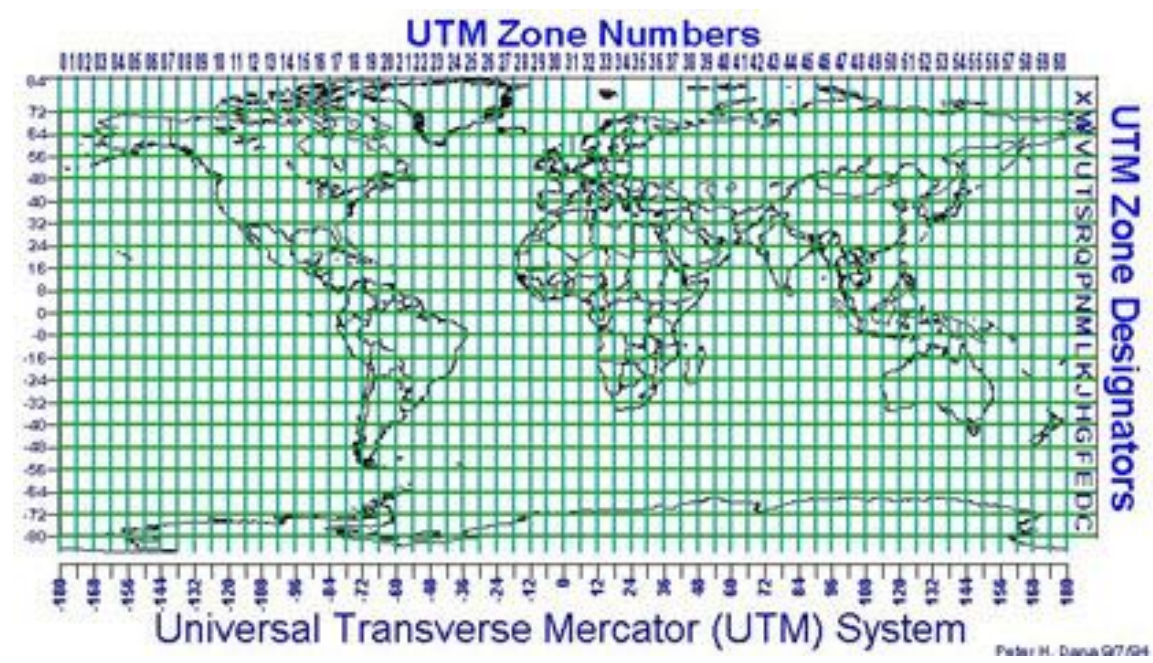

Figure 9. Universal Transverse Mercator (UTM) coordinate system

(Image accessed 27 May 2020 from

http://Www.georeference.org/doc/universal_transverse_mercator_utm_htm)

Thai Lanna mural paintings at Wat Phumin used the same idea from both examples on the grid system. The researcher divided the image of Thai Lanna mural paintings at Wat Phumin, Nan province as shown in figure10.

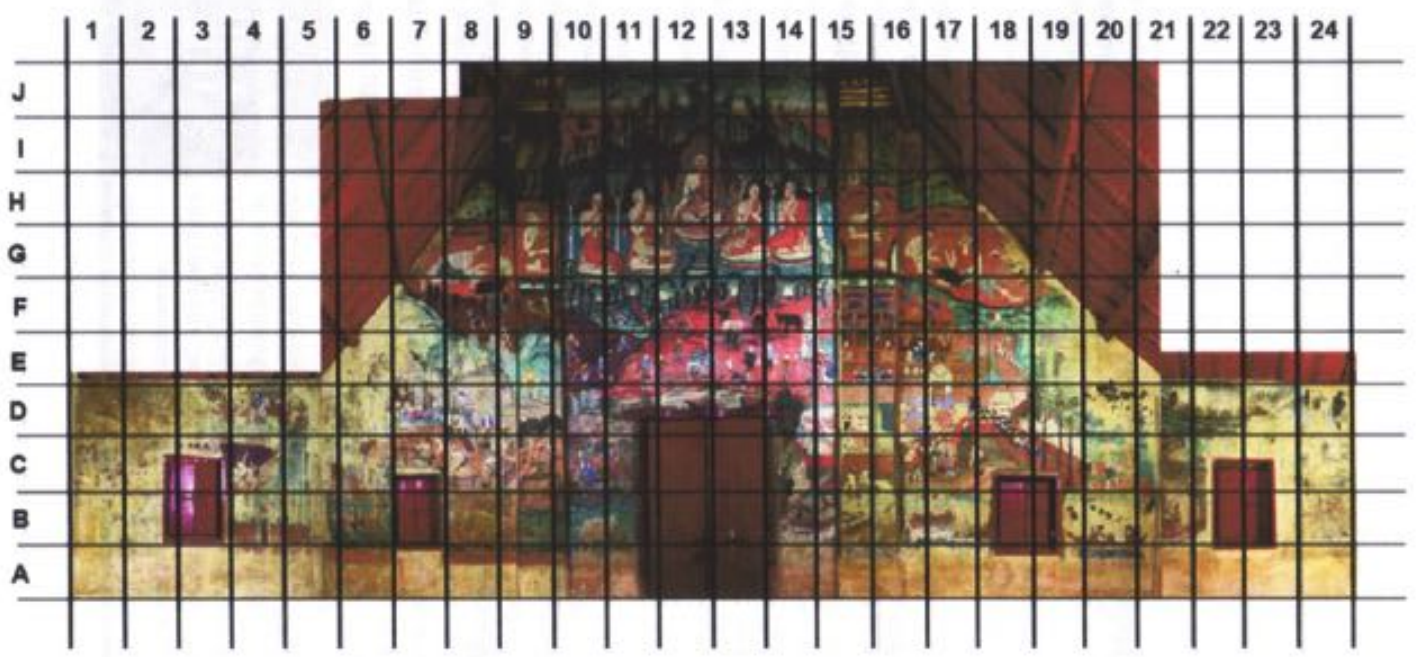

Figure 10. Divided image of Thai Lanna mural paintings at Wat Phumin

Third, the researcher used copy drawing samples of the Thai Lanna mural painting at Wat Phumin to identify the direction of storytelling on 'Previous Life Stories of the Buddha'. The content on the 'Previous Life Stories of the Buddha' 
derives from various sources. After confirming the narrative for 'Previous Life Stories of the Buddha' to be in the correct order, the direction of the storytelling starts with the north, followed by east, south, and west at Wat Phumin, as shown in figure 11 .

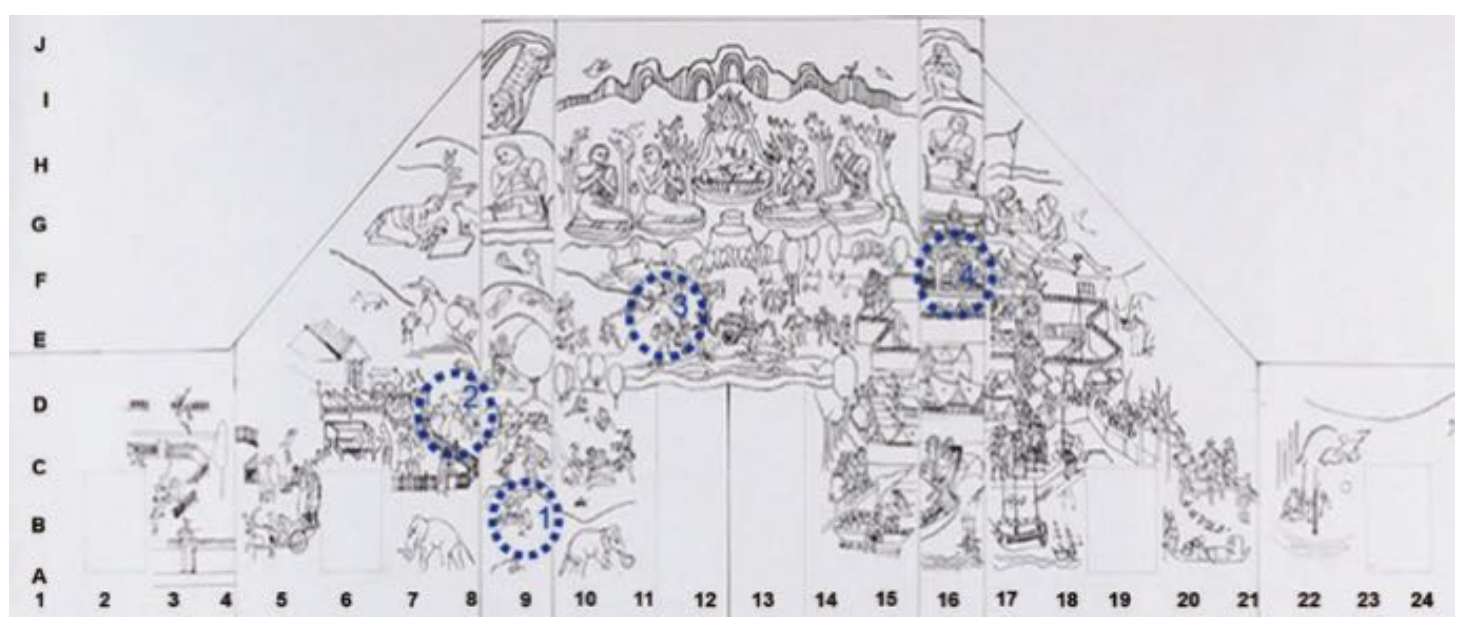

Figure 11. Order of narrative storytelling on 'Previous Life Stories of the Buddha'

As a result, there are numbers of coordination for the storytelling on 'Previous Life Stories of the Buddha' upon the four sides of the wall at Wat Phumin.

Next, this research adopted a QR code by placing them into the given positions of storytelling on 'Previous Life Stories of the Buddha' starting with episode 1 at the coordinate of point B9, and with the QR code image as given in figure 12 placed with the other coordinates respectively.

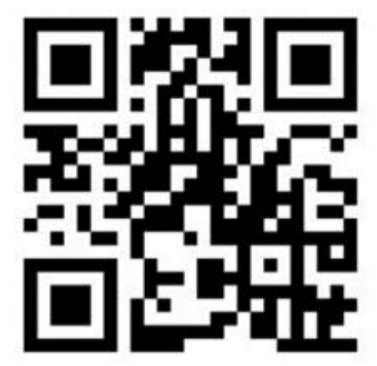

Figure 12. An example of a $Q R$ code links to the video content uploaded to YouTube (Episode 1) https://www.youtube.com/watch?v=k6Dn8bAuRSo)

All of the QR codes on the images of Thai Lanna mural paintings linked to 2D moving images for the storytelling of Panya-Jataka at Wat Phumin uploaded to YouTube. 
Tawipas Pichaichanarong, Practice-Based Research in Digital Arts: ...

In fact, the video contents on YouTube comprises 2D moving images for the storytelling of Panya-Jataka for Wat Phumin, which the researcher received funds from the Office of Contemporary Art and Culture (OCAC) Ministry of Culture, Thailand in 2017. The 2D moving images for storytelling of Panya-Jataka at Wat Phumin, Nan province totaled amounts of thirteen videos.

After that, the researcher has completed the placement 13 QR codes into 13 positions in the images of Thai Lanna mural paintings at Wat Phumin, as shown in figure 13 .

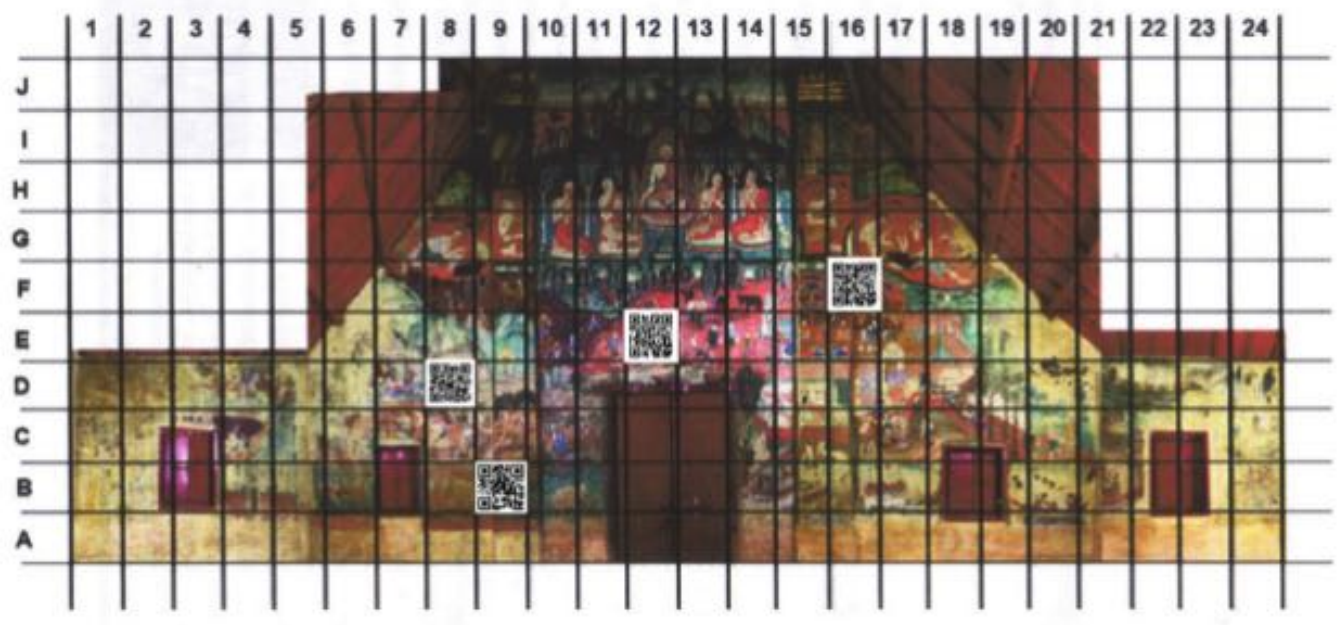

Figure 13. QR codes placed on the coordination of storytelling on 'Previous Life Stories of the Buddha'

Next, the researcher deleted the lines on the images as shown in figure 14.

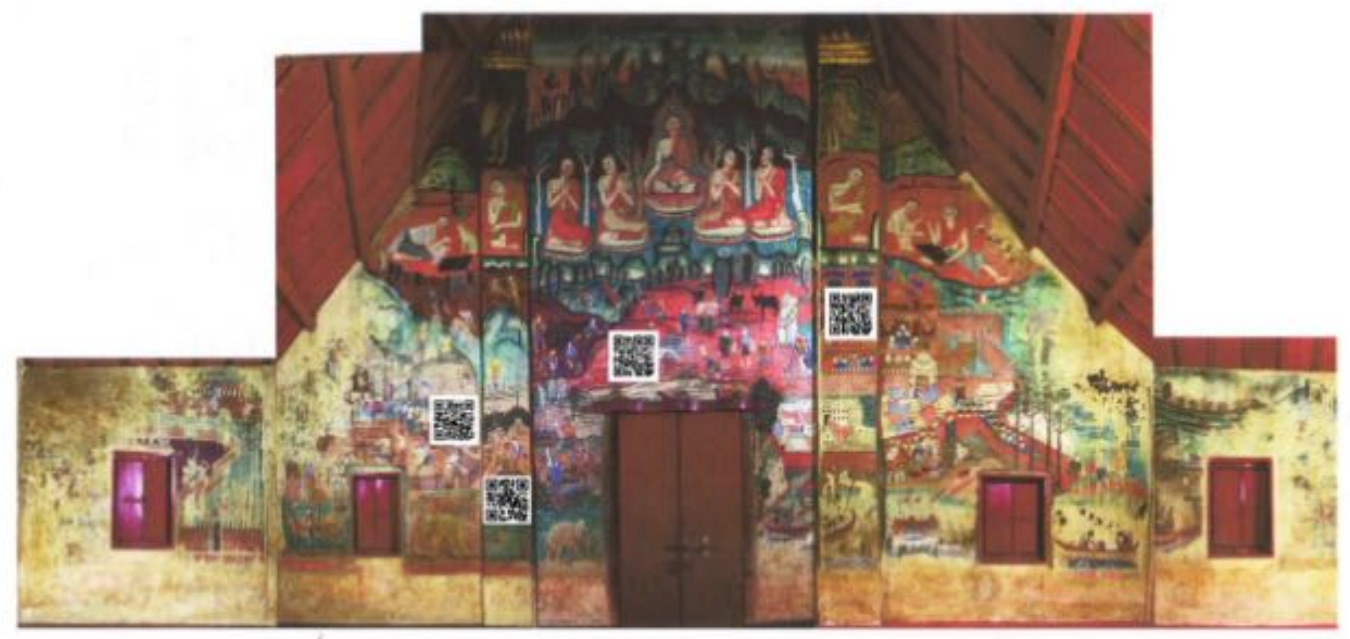

Figure 14. Final image of storytelling on 'Previous Life Stories of the Buddha' in the north 


\section{Responsive Web Design}

What is RWD?

According to Jason A. Clarke (2015), the author of the book "Responsive Web Design in Practice", the idea of building web sites that work on multiple devices and screens in order to serve the new era of digital technology with limitless power.

The responsive web design was used in this research because of its ability to work on multiple devices and screens. The researcher suggests RWD can facilitate Thai and foreign visitors to Wat Phumin, in their experience of Thai Lanna mural paintings at Wat Phumin in Nan Province.

\section{Google Sites}

For the first version of RWD, the researcher used Google Sites as a tool. Google Sites is one of the products from Google first released in 2008. Google Sites was created for anyone who wants to create a personal website. The new version of Google sites has the responsive web ability to open its website on various platforms. In addition, Tatpuje and Ganbote (2015) point out Google platform contains with number of tools and apps, use of videos, online tools, interaction through Google community.

In Thailand, there is the collaboration between Google and Thai Universities called "Google for Education" in order to help the students improve their learning and innovation (retrieved from https://edu.google.com on Feburary $28^{\text {th }}, 2019$ ).

The researcher used Google Site from Silpakorn University, Thailand for the first version of RWD as shown in figure 15.

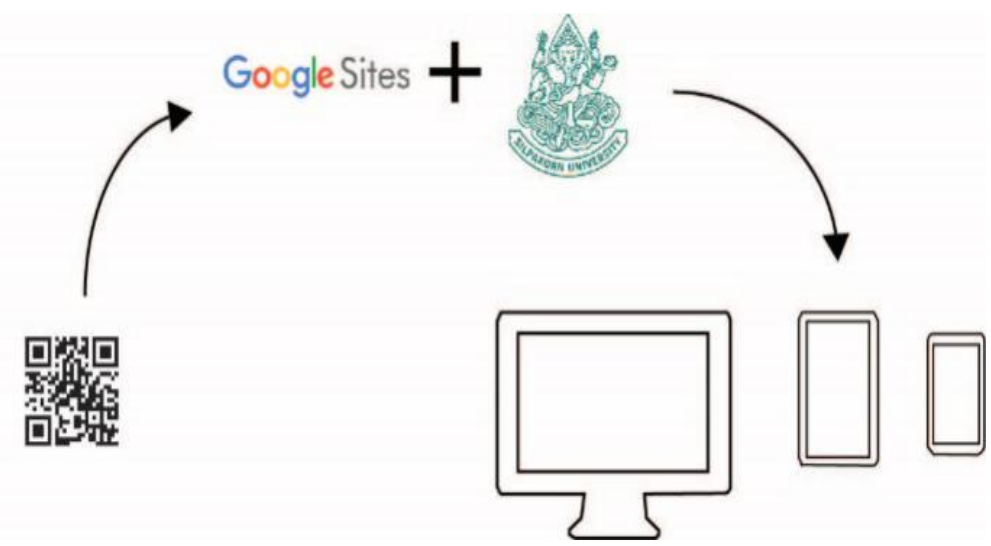

Figure 15. Google Sites version 
Tawipas Pichaichanarong, Practice-Based Research in Digital Arts: ...

\section{RWD Frameworks}

For the second version of RWD, the researcher used the RWD frameworks to create a responsive web as a tool. A framework is a collection of files-scripts, HTML, CSS, and so forth. In addition, Priyanka Panchal (2017) explains that the quality of this web properties will calibrate from mobile screen to full desktop resolution continuously.This research selected the "Bootstrap" framework (http://getbootstrap.com/). Bootstrap is the most popular of the three frameworks widely used globally presented in figure 16 .
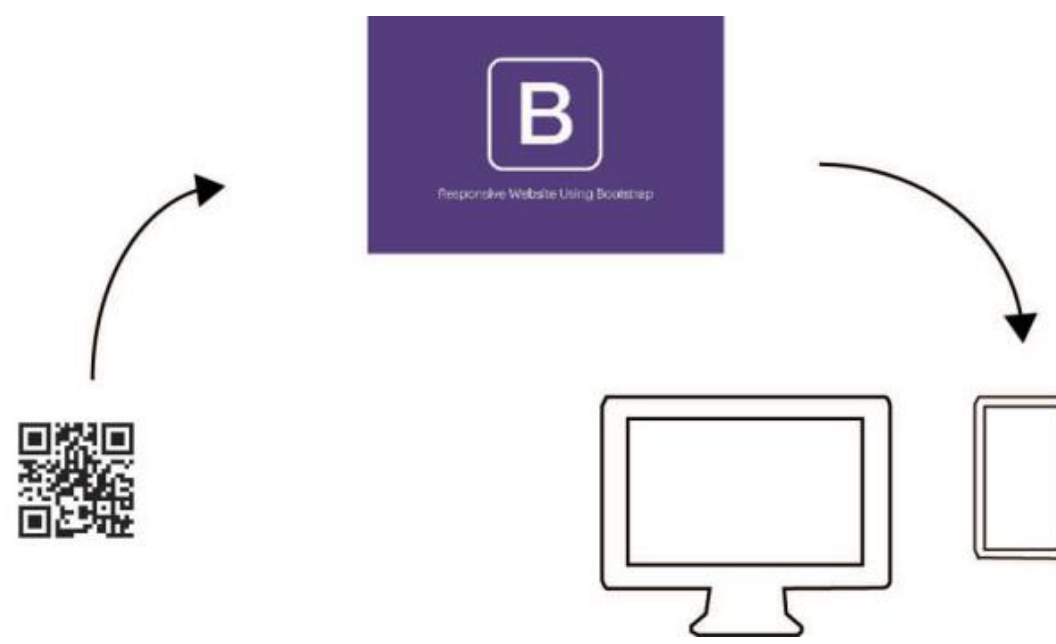

Figure 16. RWD Frameworks version

\section{DISCUSSION}

A result from both version of Google Sites and RWD Frameworks is an example of the solution in order to facilitate Thai and foreign visitors at Wat Phumin through digital technology. It is illustrated in figure 17. 
IJCAS Vol. 6 No. 2, December 2019 | p-ISSN 2339-191X | e-ISSN 2406-9760

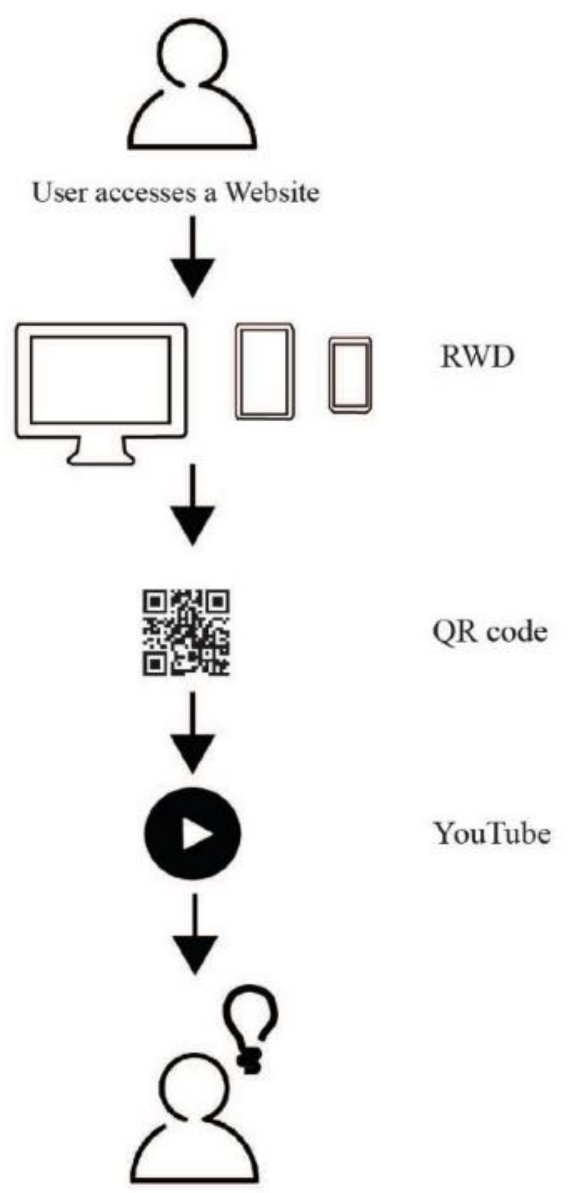

User has a better understanding of all the objectives in this research

Figure 17. A diagram of a solution to facilitate visitors at Wat Phumin through digital technology in this research

\section{Data Analysis}

This research used a practice-based research design in every steps of producing the final outcome to answer the objectives of this research. Indeed, the researcher followed all the practice-based approaches in the framework as given in figure 18 . 


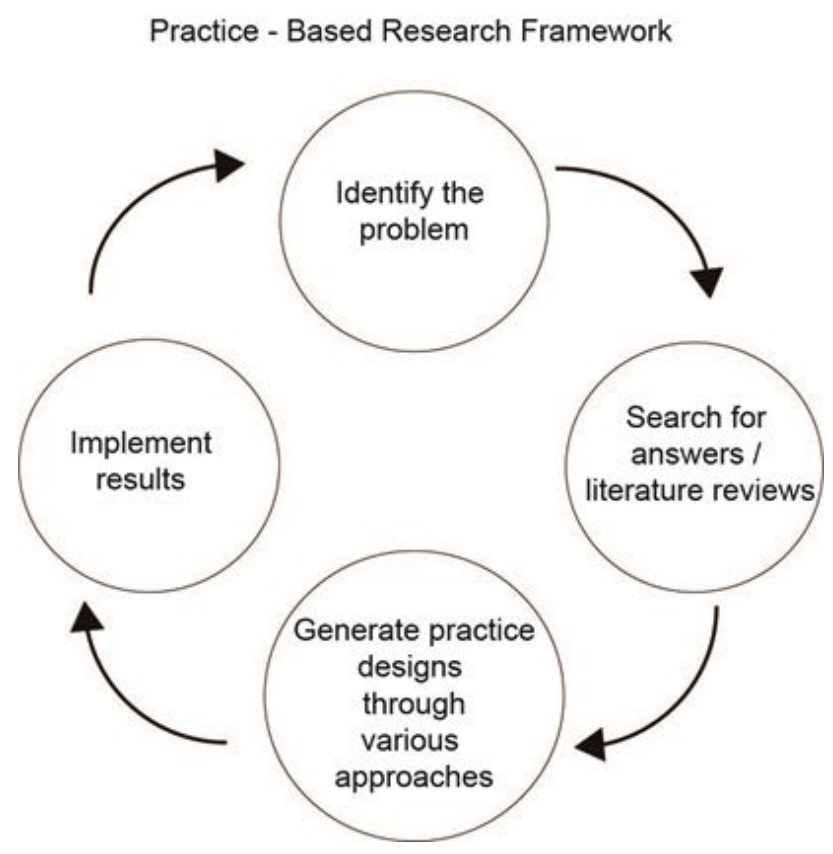

Figure 18. Practice-Based Research Design

This research focuses only on the storytelling on 'Previous Life Stories of the Buddha', with Khattana Kumara Jataka on the northern wall, the eastern wall, the south wall and the Nimi Jataka on the western wall as illustrated in figure 19.
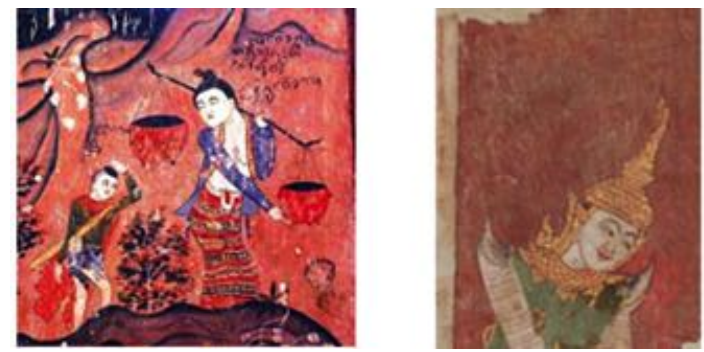

Figure 19. Khattana Kumara Jataka (left), Nimi Jataka (right)

\section{CONCLUSIONS}

In conclusion, this study has achieved all the objectives as set. However, the idea of this study derived from the creativity related to the literature review and in-depth interviews from field trips. In addition, the researcher added digital technologies in this study as well, and expects new knowledge to be derived from this experiment.

From the results from my research, I can conclude that new digital technologies can influence the ways in which individuals and institutes act as a 
museum. Susana Smith Bautista (2014), author of "Museums in the Digital Age: Changing Meanings of Place, Community, and Culture" asserts that museums (for example, Wat Phumin in Nan province) today can integrate both traditional elements and the context of the digital age to embrace the legacy of place, locality, culture, and community (p.xxi). This can then reach a modern younger generation.

\section{ACKNOWLEDGEMENTS}

I am very grateful to The 4th International Conference for Asia Pacific Arts Studies (ICAPAS 2016) committee, and The 1st International Conference on Intermedia Arts and Creative Technology (CREATIVEARTS 2019), both held in Yogyakarta, Indonesia for allowing me to begin my academic journey with ICAPAS in 2016, and other episodes with CREATIVEARTS in 2019. In addition, I would like to express my gratitude to Suan Sunandha International School of Arts, Suan Sunandha Rajabhat University, Nakhon Pathom Campus, Silpakorn University and The Office of Contemporary Art and Culture (OCAC) Ministry of Culture, Thailand for their supports. Lastly, I would like to express thanks and gratitude to my loving mother, who has supported me in every way.

\section{REFERENCES}

Bautista, S. S. (2014). Museums in the Digital Age: Changing Meanings of Place, Community, and Culture. MD: AltaMira Press.

Clark, J. A. (2015). Responsive Web Design In Practice (Library Technology Essentials). MD: Rowman \& Littlefield.

Dalferro, A. (2018). Museum NOW! Articles From Talks Presented at Academic Conferences. Bangkok: National Discovery Museum Institute.

History of QR Code How was the QR Code created? How has it come to be used so widely? And what is its future? (n.d.). Retrieved February 26, 2019, from https://www.qrcode.com/en/history/

Panchal, P. (2017). Responsive Web Design and Web Development Using Bootstrap Frond-End Framework. International Journal of Advance Research in Science and Engineering, 6 (7), 1-8. Retrieved May 15, 2019, from https://ijarse.com/images/fullpdf/149873599_GOA_1005_ijarse.pdf.

Pichaichanarong, T. (2017). Visual Methods In Social Research on Lanna Mural Painting: A Case Study of Wat Phumin, Nan Province. International Journal of Creative and Arts Studies, 3(2), 25. doi:10.24821/ijcas.v3i2.1842 
Tawipas Pichaichanarong, Practice-Based Research in Digital Arts: ...

Tatpuje, D. U., \& Ganbote, A. (2015). Study of skills development among the youths with Google integrated entrepreneurial training. Researchgate.net. Retrieved May 15, 2019, from

https://www.researchgate.net/publication/331890031_Study_of_Skills_De velopment_Among_the_Youths_With_Google_Integrated_Entrepreneurial _Training.

Vaughan, L. (2017). Practice-based design research. London: Bloomsbury Academic an imprint of Bloomsbury Publishing Plc. 